\title{
Prostate Mantle Cell Lymphoma
}

National Cancer Institute

\section{Source}

National Cancer Institute. Prostate Mantle Cell Lymphoma. NCI Thesaurus. Code C161604.

A rare mantle cell lymphoma that arises from the prostate gland. 